\title{
WATER RELATION, GAS EXCHANGE AND DRY MATTER PRODUCTION OF COCONUT (COCOS NUCIFERA, L.) UNDER UNIRRIGATED AND IRRIGATED CONDITIONS
}

\author{
K.V. Kasturi Bai, V. Rajagopal, D. Balasimha and P. Gopalasudaram ${ }^{1)}$
}

\begin{abstract}
The response of local West Coast Tall (WCT) and the two hybrids viz., WCT x Chowghat Orange dwarf (COD) and COD x WCT to moisture availability in terms of water relation, gas exchange and dry matter (DM) production was studied. Discernible differences were noticed between the irrigation treatment (viz., irrigated vs unirrigated) with lower stomatal conductance and transpiration rate in the palms with out irrigation. Irrespective of the cultivar of hybrid leaf water potential was also significantly higher in irrigated palms. Net assimilation rate was lower under uniriigated condition. However genotypic or treatment differences were not significant. Annual DM production also vaned markedly between the irrigation treatments. Treatment differences were significant on the reproductive (RDM) rather then vegetative DM (VDM) production. Under the irrigation treatment the hybrids performed better than the local tall However the percentage reduction in the DM production was relatively less in the local WCT cultivar under unirrigated as compared with irrigated condition. The studies clearly highlighted the beneficial effects of irrigation on DM production and yield in coconut and the adaptability of the local WCT variety under limited water supply than the two hybrids.
\end{abstract}

\section{INTRODUCTION}

Coconut is a crop of humid tropics. Although it is grown under unirrigated conditions the beneficial effects of inigation on nut production has been reported by many workers (Nelliat and Padmaja, 1978 and Abeywardena, 1983). Due to its perennial nature, weather parameters (Kasturi Bai et al., 1988) and the water holding capacity of the soil (Voleti et al., 1993) are found to influence the water relations of this crop. In an earlier study, Rajagopal et al., (1989) reported the influence of different frequencies of irrigation on the leaf water relation and dry matter production of West Coast Tall coconut palms. Based on the study, they could establish the critical soil water deficit which would be useful for scheduling irrigation. In another study Shivashankar et al., (1991) reported the biochemical changes occurring in the palms under unirrigated and irrigated conditions through the activities of some enzymes sensitive to water stress. Recently Kasturi Bai et al., (1996) have evaluated the coconut cultivars and hybrids for DM production and identified the traits for higher DM production.

Impact of irrigation on the growth, DM production characteristics and yield of various crop plants has been well documented in the literature (Kozlowski, 1981). Although the positive response of coconut palms to summer irrigation in terms of nut yield was reported earlier (Nelliat and Padmaja, 1978), there was no systematic attempt to compare the varietal responses to water availability in relation to yield related parameters. Hence, studies were conducted to understand the water relation, gas exchange, DM production and yield among WCT and the two hybrids WCT $\mathrm{x}$ Chowghat Orange Dwarf (COD) and COD x WCT under unirrigated and irrigated conditions.

\footnotetext{
${ }^{1}$ Central Plantation Crops Research Institute, Kasaragod - 671 124, Kerala.
} 


\section{MATERIALS AND METHODS}

Adult coconut palms of stabilized yield group ( 22 year old) growing in red sandy loam soil with a spacing of $7.5 \times 7.5$ metres in the Institute farm were the materials for the observations. They were the local tall cultivar WCT and the two hybrids WCT x COD and COD x WCT. The experiment was laid out in a strip plot design, with WCT and hybrid in one direction and irrigated vs unirrigated in the other direction. The plot size was three palms. Irriigation water was supplied through perfo spray at the rate of $25 \mathrm{~mm}$ of water at a frequency equal to the $1 \mathrm{~W} / \mathrm{CPE}$ ratio of 0.75 . The experimental palms received 500g N, 500g $\mathrm{P}_{2} \mathrm{O}_{5}$ and $1000 \mathrm{~g} \mathrm{~K}_{2} 0 \mathrm{palm}^{-1}$ year $^{-1}$. The observations were recorded from two palms plot-1 during February/March of two dry seasons. The mean of six palms cultivar / hybrids ${ }^{-1}$ and for the two chy seasons was considered for the interpretation. of the results. The analysis of variance was carried out in two factor strip plot design.

Soil moisture content was determine at four depths viz., 0-30, 30-60, 60-90 and 90-120 cms, in the basins of palms under irrigated and unirrigated treatment with the Troxler Neutron Probe (model 3222, USA). Under irrigated condition soil moisture content was determine one day after irrigation.

Leaf water potential (?) was determined by using the Scholander Pressure Chamber (Plant water console, model 3000, Soil moisture Co, USA) following the method of Milburn and Zimmermann (1977). The net carbon assimilation rate (Pn) and other related parameters viz., stornatal conductance (gs) and transpiration rate (Tr) were determined by using portable photosynthesis system ( $\mathrm{Li} \mathrm{6200,} \mathrm{Li} \mathrm{Cor} \mathrm{Inc,} \mathrm{USA).} \mathrm{The} \mathrm{same} \mathrm{instrument} \mathrm{simultaneously} \mathrm{measures}$ all the micro meteorological variables viz., radiation (PAR), temperature and vapour pressure deficit (VPD) as well as ambient $\mathrm{CO}_{2}(\mathrm{Ca})$ and internal $\mathrm{CO}_{2}(\mathrm{Ci})$ concentrations. All the determinations were made between 10.00 and 11.30 hours which was found to be the appropriate time to study the stomatal regulation in coconut (Kasturi Bai et al., 1988).

Growth characteristics such as increment in stern height and leaf production were recorded annually, where as the female flower production and fruit set were recorded monthly. Both vegetative $(\mathrm{VDM})$ and reproductive $\mathrm{DM}(\mathrm{RDM})$ production were computed from the above observations by employing the regression equations ( Ramadasan and Mathew, 1987; Rajagopal et al., 1989). For RDM production, dry weight of the nut which is a total of dry weight of husk, shell and copra as well as the dry weights of spathes and bunches was determined separately.

\section{RESULT AND DISCUSSION}

The agrometeorological variables in the vicinity of the palms during the experimental period were PAR $1208 \pm 34 \mu \mathrm{molm}^{-2} . \mathrm{S}^{-1}$, temperature $31.2 \pm 1.7^{0} \mathrm{C}$, VPD $2.6 \pm 0.08 \mathrm{KPa}$ and ambient $\mathrm{C}_{2}$ concentration about $330 \mathrm{ppm}$. In the basins of irrigation treatment, soil moisture content (percentage by volume basis) at 30, 60, 90 and 120 cins depths was 17.6, 18.0, 18.2 and 18.5 respectively, while under no irrigation it was 8.0,10.9, 12.0 and 12.7. The field capacity of this soil (corresponding to $0.03 \mathrm{Mpa}$ ) varied from $13.5 \%$ to $18.5 \%$ volumetric moisture content from the upper to lower soil depths ( 0 to $120 \mathrm{~cm}$ ), whereas the permanent wilting point ( $-1.5 \mathrm{Mpa}$ ) varied from $7.5 \%$ to $10.0 \%$ (Rajagopal et al., 1989). From this it is evident that a difference of about $9 \%$ to $6 \%$ in soil moisture existed between the treatments at given depths. This implies that with all the parameters remaining the same, moisture content in the soil was the only limiting factor and the differences observed if any could be attributed to the moisture avaliability to the palms for their growth and DM production. Although, the permanent wilting point was not reached, the fact the soll moisture content in unirrigated basin was closer to it reveals the extent of damage to the plant system, which is described below. 


\section{Water Relation and Gas Exchange}

The protective role of stomatal regulatory mechanism in coconut during moisture stress has been reported by Milburn and Zimmerman (1977) and Rajagopal et al., (1989). As compared with the irrigated condition the palms under no irrigation showed discernible differences in the water relations and gas exchange characteristics (Table. 1). Significantly higher ? (18\%) was observed in the palms with irrigation than in the palms without irrigation. But genotypic differences were not observed. Under the unirrigated condition higher reduction in ? was observed in the WCT than the hybrids. The low ? in the palms under no irrigation induced stomatal closure thus reducing further water loss by transpiration. As compared with unirrigated condition significantly higher $\mathrm{Tr}$ rate $(36 \%)$ was observed in the palms with irrigation. Tr rate was $50 \%$ lower in WCT under no irrigation as compared with the irrigation. However it did not vary much under both the treatments in COD $\mathrm{x}$ WCT. That is, this hybrid had relatively high transpirational loss of water under rainfed condition as compared to other two genotypes. This corroborate with the earlier observation of Rajagopal et al., (1990) that COD x WCT is most sensitive to limited water availability.

Stomatal conductmice (gs) was $52 \%$ higher under irrigated as compared with the unirrigated conditions. Under unirrigated condition lower gs was observed in WCT $\left(99.3 \mathrm{~m} . \mathrm{mol} \mathrm{m}^{-2} \mathrm{~S}-\mathrm{-}^{-}\right)$and higher in COD x WCT $\left(202.7 \mathrm{~m} . \mathrm{mol} \mathrm{m} \mathrm{m}^{-2} \mathrm{~S}^{-1}\right.$. The higher Tr observed in COD x WCT under no irrigation can be attributed to the higher gs. The susceptibility of this hybrid during drought situation reported by Rajagopal et. al., (1990) could thus be attributed to the higher gs leading to higher loss of water by Tr. Parallel with the reduction in gs, Pn rate also showed a decrease (20.3\%) under unirrigated condition as compared with the irrigated condition, However genotypic or treatment differences were not significant for Pn rate. The reduction in gs $(34.1 \%)$ was more than the reduction in Pn rate. Schulze and Hall (1982) showed that under drought situation, at ambient $\mathrm{C}_{2}$ concentration stomata of $\mathrm{C}_{3}$ plants generally decrease their aperture prior to the changes in the photosynthetic capacity. In Nerium sp. also Gollan et al (1985) have reported similar trend.

The reduction in gs lead to lowering of $\mathrm{Ci}$ mi the palms under unirrigated condition whereas under unirrigated condition it ranged between 221.4 and $230.7 \mathrm{ppm}$ leading to a reduction of $7.1 \%$. Such decrease in $\mathrm{Ci}$ in the water stressed pea plants has been reported by Comic and Briantais (1991). The Pn/Ci ratio, which indirectly measure the carboxylation efficiency ( Farquhar and Sharkey, 1982) did not show significant difference between the genotypes or between the treatments. In conifers Brodribb (1996) also has reported no difference in the carboxylation efficiency between droughted and undroughted plants until a threshold level of $\mathrm{Ci}$ has reached. The nonsignificant difference observed in the ratio of $\mathrm{Ci} / \mathrm{Ca}$ between the irrigated $(0.74)$ and unirrigated $(0.70)$ conditions supports this.

The level of $\mathrm{Ci}$ is controlled by stomatal as well as non-stomatal factors i.e., stomatal efficiency as well as mesophyll efficiency which incorporate $\mathrm{CO}_{2}$ by the carboxylation processes (Farquhar and Sharkey, 1982). Sheshshayee et al., (1996) have shown an inverse relationship between Pn rate and $\mathrm{Ci} / \mathrm{gs}$ ratio and have stressed the importance of $\mathrm{Ci} / \mathrm{gs}$ ratio as an indicator of mesophyll efficiency. The lower $\mathrm{Ci}$ under unirrigated condition can be attnibuted to the higher efficiency of the mesophyll to fix the available substrate $\mathrm{CO}_{2}$. As compared to irrigated condition the ratio of CI/gs as well as Pri/gs showed an increase (48.7\% and $24.1 \%$ respectively) indicating higher mesophyll capacity thus mamitahiing higher Pn rate under unirrigated condition. Between the genotypes higher increase in Pn was observed in WCT than the hybrids.

Although instantaneous WUE ( $\mathrm{Pn} / \mathrm{Tr}$ ) did not show any significant difference, it was $13 \%$ higher in the unirrigated palms. Higher WUE under unirrigated condition has been reported in Wheat ( Aggarwal and Sinha, 1983) and in coconut (Rajagopal et al, 1989). Higher WUE associated with higher stomatal resistance and lower Pn rate also has been reported by Fischer and Tumer (1978). The results thus indicate that coconut palms regulate the water balance under stress 
condition with least effect on the Pn rate. Similar result also has been reported in cocoa by Balasimha et al (1991).

\section{Dry Matter Production}

Understanding the control processes of DM production will help to understand the adaptive mechanism of plants to water limited enviromnents (Smith, 1989). Foale (1993) also has highlighted the importance of studies on DM production for improving the productivity of coconut. Annual DM production varied greatly between unirrigated and irrigated conditions ( Table 2). As in other annual crops (Aggarwal and Sinha, 1983) DM production of the reproductive parts of the palms are affected more than the vegetative parts. Irrespective of the irrigation treatment higher VDM production was observed in WCT $(42.1 \mathrm{~kg})$ than COD x WCT $(38.9 \mathrm{~kg})$ and the reverse was, observed in RDM production. This corroborates with the earlier observation of Kasturi Bai et al (1996) that the talls produce higher VDM whereas the hybrids produce higher RDM. Genotypic or treatment differences were not found in the VDM production, whereas the RDM production showed significant differences $(\mathrm{P}=5 \%)$ between irrigated and unirrigated palms. RDM production ranged between 65.8 $\mathrm{kg}$ and $78.9 \mathrm{~kg}$ in the unirrigated palms whereas under irrigation it ranged from $77.2 \mathrm{~kg}$ to $95.4 \mathrm{~kg}$. The fact that VDM production did not show any significant difference between the irrigated and unirrigated palms reveal that the partitioning of DM towards pield is affected more by moisture stress than the vegetative parts. Rajagopal et al., (1989) also have reported higher VDM production at the expense of RDM production during water deficit condition in coconut. This shows that there is no plasticity in the VDM production in coconut as seen in some determinate crops (Sobrado and Turner, 1986). RDM production mainly depends on the dry weight of the nut and the partitioning of the dry matter towards its components viz; husk shell and copra (Kasturi Bai et al., 1996).

\section{Female flower production and yield}

Female flower production and yield showed significant differences only between the irrigation treatment (Table 3). Irrespective of the cultivar or hybrid female flower production palm ${ }^{-1}$ year $^{-1}$ was less in the unirrigated palms (range 326 - 408) than those with irrigation ( range 431-504). Irrigation of palms resulted in $29 \%$ increase in the female flower production compared to those that remained unirrigated. Under both the treatments the female flower production. (No.) was higher in COD x WCT (456) thanmi WCT (379) and in WCT x COD (415), but fruit set was comparatively lower in this hybrid (30\%) than WCT and WCT x COD ( 33 to 35\%) Nut production showed about $26 \%$ increase under irrigation as compared with the unirrigated condition. This indicates that coconut palms respond positively to yield when water availability is ensured. However, genotypic or treatment differences were not signifficant due to the high variation observed in the nut production $(\mathrm{CV}=29 \%)$. Nut production (No.) also was found to be higher in the two hybrids (range 137 - 141) than the WCT (127) under irrigation. A similar trend occurred in palms without irrigation. However, as compared with the unirrigated condition the nut production under irrigation was highermi WCT (29\%) than WCT x COD (26\%) and COD x WCT (24\%). The impact of water deficit on total dry weight of the nut also has been reported earlier (Anonymous 1988) which indicate that the reduction in the dry weight of the nut in COD x WCT was $16 \%$ in the unirrigated palms as against only $1 \%$ and $5 \%$ respectively in WCT $x$ COD and WCT.

Copra out-turn also showed an increase of $36 \%$ under irrigation as compared with unirrigated condition. Out turn of copra was higher in the two hybrids than in WCT under irrigated condition. However the reduction in the copra outturn under unirrigated condition was only $17 \%$ in WCT as against $34 \%$ and $27 \%$ respectively in WCT x COD and COD x WCT. Between the two hybrids although higher reduction in copra outturn was seen in WCT x COD, the copra content nut- 1 was found to be drastically affected in COD x WCT under unirrigated condition (Anonymous 1988). 
In an earlier study based on the relationship between the soll water deficit, stomatal resistance and DM production, Rajagopal et al., (1989) have indicated the critical soil water deficit above which the palms show drought symptoms. The same authors (Rajagopal et al., 1992) have also reported significant correlation between the stress sensitive parameters and nut yield. Recently, Kasturi Bai et al., (1996) have observed significant correlation between WUE and DM production charactcristics such as RDM and TDM urider rainfed cultivation, whereas Pn rate did not show any correlation. In the present study also the Pn rate did not show significant difference between the two treatments. This signifies that coconut palms maintain the water balance by reducing the water loss through stomatal closure without disrupting the Pn rate.

\section{CONCLUSIONS}

The differential response of local tall and the two hybrids to moisture availability in terms of gas exchange DM Production and yield is highlighted in the study. The present work thus confirms the earlier observations of Nelliat and Padmaja (1978) and Rajagopa et al., (1989) that irrigation has defmite influence on the productivity of palms. The results further show that although the hybrids are characterized by higher DM production in response to inigation, greater reduction of the same was observed when exposed to moisture stress, than the situation obtained with local WCT variety. This indicate that the WCT variety suffer relatively less under limited water supply than the hybrids.

\section{ACKNOWLEDGMENTS}

The authors wish to record their sincere gratitude to Dr. MK Nair, Director, CPCRI Kasaragod for providing the facilities for carrying out the work. Our thanks are also due to Mr. C.H. Amamath for the statistical analysis of the data and Mrs. C.D. Prabha for the technical help. 


\section{REFERENCES}

Abeywardena, V. (1983). Effect of moisture stress and irrigation on yield of coconut in Sri Lanka. In. Nayar, NM (ed.) Coconut Research and Development. Wiley Eastern Ltd. pp. 98-106

Aggarwal, P.K. and Sinha, S.K. (1983). Water stress and water use efficiency in field grown wheat. A comparison of its efficiency with that of C, plants. Agric. Meteorol. 29:159-167

Anonymous (1988). Annual Report of 1987, CPCRI Kasragod pp. 49-53.

Balasunha, D; Daniel, E.V. and Bhat, P. G. (1991). Influence of environmental factors on photosynthesis of cocoa trees. Agric. Forest. Meteorol. 55:15-21

Brodribb, T. (1996). Dynamics of changing intercellular CO, concentration. (Ci) during drought and determination of minimurn functional Ci. Plant physiol. 111: 179-185

Cornic, G. and Bniantais, J.M. (1991). Partitioning of photosynthetic election flow between $\mathrm{CO}_{2}$ and $\mathrm{O}_{2}$ reduction in a $\mathrm{C}_{3}$ leaf (Phaseolus vulgaris) at different $\mathrm{CO}_{2}$ concentration and during drought stress. Planta 183: 178-184.

Farguhar, G.D. and Sharkey, T.D. (1982). Stornatal conductance and photosynthes1s. Ann. Rev. Plant. Physiol. 33:317-345.

Fischer, R-A. and Turner, N.C. (1978). Plant productivity in the and zones. Ann. Rev. Plant. Physiol. 29:277-317

Foale, M. A. (1993). Physiological basis for yield in coconut. In Nair, M.K., H.H. Khan, P. Gopalasundaram and E.V.V. Bhaskara Rao (des.). Advances in Coconut Research and Development Oxford and IBH Publishing Co. PVT. Ltd., New Delhi pp. 181-189

Gollan, T; Tumer, N.C. and Schulze, E.D. (1985). The responses of staniata and leaf gas exchange to vapour pressure deficit and soll water content. III. In the sclerophyllous woody species in Nerium oleander: Oecologia 65:356-362.

Kasturi Bal K.V., Voleti, S.R. and Rajagopal, V. (1988). Water relations of coconut palms as influenced by environmental variables. Agric. Forest. Meteorol. 43: 193-199.

Kasturi Bal, K.V., Rajagopal, V., Prabha, CA, Ratnambal, M.J. and George, M.V. (1996). Evaluation of coconut cultivars and hybrids for dry matter production J. Plantation crops $24: 23-28$

Kozlowsld, T. T. (1981). Woody Plant Communities. In: Water deficits and plant growth. T.T. Kozlowski (ed.) Vol. VI. Academic press. Inc. New York.

Milburn, J.A., Zimmerman, M.H. (1977). Preliminary studies on sap flow in Cocos nucifera, L. I. Water relations in xylem transport. New Phytol. 79: 535-541.

Nelliat, E.V., Padmaja, P.K. (1978). Irrigation requirement of coconut arid response to levels of fertilizer under irrigated condition during the early bearing stage. In: Nelliat E.V. (ed.) Proc. Placrosyrn 1. Kasaragod. pp. 186-189.

Rajagopal, V., Ramadasan, A., Kasturi Bai, K.V., Balasimha, D. (1989). Influence of irrigation on leaf water relations and dry water production in coconut palms. Irrig. Sci. 10:73-81 
Rajagopal, V., Kasturi Bal, K.V., Voleti, S.R., Shivashankar, S. (1990). Water stress in coconut palms (Cocos nucifera L.) In: Sinha, S.K., P.V. Sane, S. Bhargawa, P.K. Aggarwal, (eds.) Proceedings International Congress on Plant Physiology. Vol. 1. pp. 508-512

Rajagopal, V., Kasturi Bai, K.V., Pillai, R.V. and Vijayakumar K. (1992). Relationship between physiological characters and nut yield in coconut genotypes under rainfed condition. J. Plantn. Crops. 20 (Suppl): 277 - 283.

Ramadasan, A. And Mathew, J. (1987). Leaf area and dry matter production in adult coconut palms. J. Plantn. Crops 15: 59-63

Schulze, E.D., Hall, A.E. (1982). Stomatal responses, water loss and $\mathrm{CO}_{2}$ assimilation rates of plants in contrasting environments. In: Lange, O.L., P.S. Nobel, C.B. Osmond and H. Zigler (eds.) Physiological Plant Ecology II Water relations and carbon assimilation. Encyclopedia of Plant Physiology 12 B. Springer Verlag. pp. 181 - 230

Sheshshayee, M.S., Krishmaprasad, B.T., Nataraj, K.N., Shankar, A.G., Prasad, T.G. and Udayakumar, M. (1996). Ratio of intercellular $\mathrm{CO}_{2}$ concentration to stomatal conductance is a reflection of mesophyll efficiency. Curr. Sci, 70(7): $672-675$.

Shivashankar, S., Kasturi Bai, K.V., Rajagopal, V. (1991). Leaf Water potential, stomatal resistance and activities of enzymes during the development of moisture stress in the coconut palm. Trop. Agric. 68: 105-110.

Smith, B.G. (1989). The effect of soil water and atmospheric vapour pressure deficit on stomatal behaviour and photosynthesis in the oll palm. J. Expt. Bot. 40: 647-651

Sobrado, M.A., Tumer, N.C. (1986). A comparison of the water relation characteristics of Helianthus annuus and Helianthus petiolaris when subjected to water deficits. Oecologia 58: $308-313$

Voleti, S.R., Kasturi Bai, K.V., Nambiar C.K.B., Rajagopa, V. (1 993). Influence of soil type on the development of moisture stress in coconut. Oleagineux 46(12): 505-509. 


\begin{tabular}{|c|c|c|c|c|c|c|c|c|c|}
\hline \multirow[b]{2}{*}{ Parameters } & \multicolumn{4}{|c|}{ Unirrigated } & \multicolumn{4}{|c|}{ Irrigated } & \multirow{2}{*}{$\begin{array}{l}\text { cd: } P=5 \% \\
\text { for Irri vs } \\
\text { Unirri }\end{array}$} \\
\hline & WCT & WCTxCOD & CODXWCT & Mean & WCT & WCTXCOD & CODXWCT & Mean & \\
\hline W & -1.2 & -1.3 & -1.4 & -1.3 & -1.0 & -1.1 & -1.2 & -1.07 & $0.179 *$ \\
\hline Gs & 99.3 & 147.7 & 202.7 & 149.9 & 269.3 & 210.3 & 208.3 & 227.3 & $67.56^{\star}$ \\
\hline $\mathrm{Tr}$ & 2.58 & 3.53 & 4.90 & 3.67 & 5.16 & 5.07 & 4.77 & 5.0 & $0.491^{\star *}$ \\
\hline $\mathrm{Pn}$ & 5.09 & 6.95 & 7.41 & 6.48 & 9.41 & 7.80 & 7.57 & 8.26 & NS \\
\hline $\mathrm{Ci}$ & 221.4 & 228.2 & 230.7 & 226.8 & 252.1 & 238.3 & 241.9 & 244.1 & $17.1^{*}$ \\
\hline $\mathrm{Pn} / \mathrm{Tr}$ & 2.0 & 2.0 & 1.5 & 1.88 & 1.91 & 1.57 & 1.62 & 1.7 & NS \\
\hline $\mathrm{Ci} / \mathrm{gs}$ & 2.49 & 1.60 & 1.28 & 1.77 & 0.99 & 1.29 & 1.23 & 1.19 & $0.498^{* \star}$ \\
\hline Pn/gs & 53.3 & 47.5 & 40.3 & 47.0 & 36.3 & 39.5 & 37.9 & 37.9 & $3.287^{*}$ \\
\hline \multicolumn{10}{|c|}{ 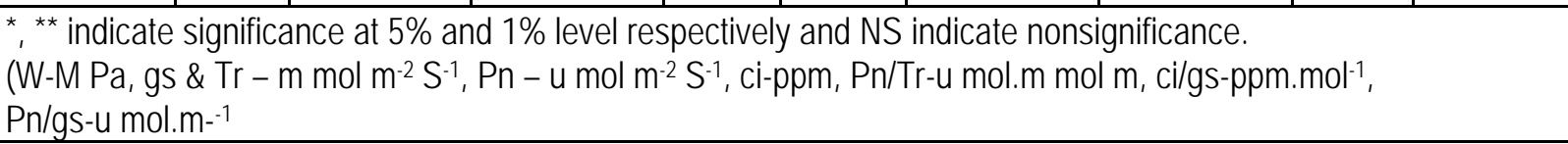 } \\
\hline
\end{tabular}

\begin{tabular}{|l|c|c|c|}
\hline \multicolumn{3}{|c|}{$\begin{array}{c}\text { Tabe 2: DM production characteristics (kg palm } \\
\text { Cultivar/hybrid } \text { year }^{-1} \text { ) in coconut } \\
\text { under unirrigated and irrigated conditions }\end{array}$} \\
\hline Cultivar/hybrid & VDM & RDM & TDM \\
\hline Unirrigated & 41.3 & 65.3 & 106.6 \\
WCT & 40.2 & 70.8 & 111.0 \\
WCT x COD & 37.7 & 78.9 & 117.6 \\
COD x WCT & 40.1 & 71.7 & 111.7 \\
$\quad$ Mean & 43.1 & & 120.3 \\
\hline Irrigated & 42.9 & 77.2 & 138.3 \\
WCT & 39.4 & 95.4 & 129.6 \\
WCT x COD & 41.8 & 90.2 & 129.4 \\
COD x WCT & NS & 87.6 & $9.71 *$ \\
$\quad$ Mean & & $8.74 *$ & \\
\hline CD: p. 5\% for & & \\
Irri. vs. Unirri. & indicated significance at 5\% and & \\
\hline NS indicate nonsignificance & &
\end{tabular}




\begin{tabular}{|l|c|c|c|}
\hline \multicolumn{3}{|c|}{$\begin{array}{c}\text { Tabe 3: Yield characteristics in coconut cultivar/hybrids under } \\
\text { unirrigated and irrigated conditions. (Palm }\end{array}$ year $^{-1}$ ) } \\
\hline Cultivar/Hybrid & $\begin{array}{c}\text { Female flower } \\
\text { Production } \\
\text { (No.) }\end{array}$ & $\begin{array}{c}\text { Nut Production } \\
\text { (No.) }\end{array}$ & $\begin{array}{c}\text { Copra outturn } \\
\text { (Kgs) }\end{array}$ \\
\hline Unirrigated & 326.3 & 110.8 & 21.8 \\
WCT & 356.2 & 125.5 & 20.3 \\
WCT x COD & 408.3 & 122.2 & 21.6 \\
COD x WCT & 363.6 & 119.5 & 21.3 \\
\multicolumn{1}{|c|}{ Mean } & 431.7 & 143.2 & 26.1 \\
\hline Irrigated & 474.5 & 157.3 & 31.0 \\
WCT & 504.7 & 151.3 & 29.5 \\
WCT x COD & 470.3 & 150.6 & 28.9 \\
COD x WCT & $24.3 * *$ & N.S. & $1.776^{* *}$ \\
Mean & & & \\
\hline CD: p. 5\% for & \multicolumn{3}{|l|}{} \\
Irri. vs. Unirri. & indicated significance at 5\% and & & \\
\hline NS indicate nonsignificance & & & \\
\hline
\end{tabular}

